\title{
MODEL PEMBERDAYAAN KELEMBAGAAN LOKAL SEBAGAI WAHANA PENDIDIKAN PENGEMBANGAN USAHA
}

\author{
Oleh : Sukidjo dan Ali Muhson \\ Universitas Negeri Yogyakarta (e-mail:sukidjo@uny.ac.id
}

\begin{abstract}
Abstrak: Model Pemberdayaan Kelembagaan Lokal Sebagai Wahana Pendidikan Pengembangan Usaha. Tujuan penelitian ini adalah mengetahui : (1) permasalahan yang dihadapi kelompok usaha warga miskin dalam mengembangkan usaha; (2) kegiatan pemberdayaan yang dilakukan Tim Konsultan Manajemen Wilayah (KMW) terhadap lembaga lokal; (3) kegiatan pemberdayaan yang dilakukan lembaga lokal terhadap kelompok usaha dalam mengembangkan usaha. Penelitian ini merupakan R\&D, dilakukan di Provinsi Yogyakarta. Penentuan sampel dilakukan secara random. Pengumpulan data dilakukan dengan kuesioner, interview dan dokumentasi. Sedangkan untuk analisis data digunakan analisis deskriptif kualitatif. Berdasarkan analisis data diperoleh simpulan : (1) permasalahan utama yang dihadapi kelompok usaha warga miskin adalah kekurangan modal kerja, bahan baku dan pemasaran; (2) Kegiatan pemberdayaan yang dilakukan Tim KMW kepada lembaga lokal berupa pelatihan dan pendampingan; (3) kegiatan pemberdayaan yang dilakukan lembaga lokal terhadap kelompok usaha berupa pelatihan, bimbingan, pendampingan melalui program pinjaman bergulir, pelatihan keterampilan dan pembangunan permukiman dan lingkungan.
\end{abstract}

Kata Kunci: pemberdayaan dan pengembangan usaha

\begin{abstract}
Local Institutional Empowerment Model As A Educational for Bisnis Development. The objective of this study were to identify : (1) the problem facing the poor in developing their business; (2) empowerment activities that was undertaken by Regional Management Consultant Team towards local institution; (3) empowerment activities that was undertaken by local institution toward business groups in order to developing their business activity. This study was R \& D, and undertaken in Yogyakarta Province. Samples were randomly selected. Data were obtained through questionnaire, interview, and documentation. Data analysis used descriptive qualitative analysis. Conclusion of this study were : (1) the main problem faced by business group of the poor is lack of capital, raw materials, and marketing; (2) empowerment activities that was undertaken by Regional Management Consultant Team towards local institution were training and mentoring; (3)empowerment activities that was undertaken by local institution toward business groups in order to developing their business activity were training, guidance, assistance through revolving loan program, skills training, and development of settlement and environment
\end{abstract}

Keywords : empowerment and bisnis development 


\section{PENDAHULUAN}

Pemerintah Indonesia sebagai anggota dalam MGDs berkomitmen untuk mengurangi kemiskinan sebesar 50\% pada tahun 2015 sesuai keputusan Deklarasi Millenium untuk Pembangunan Berkelanjutan yang dilaksanakan di Johannesburg pada tahun 2008. Sebagai tindak lanjut, Pemerintah Indonesia menekankan setiap departemen untuk mendukung dan melaksanakan program pengentasan kemiskinan. Masalah kemiskinan tidak semata-mata dengan masalah ekonomi, tetapi berkaitan juga dengan masalah ideology, politik, keamanan maupun sosial budaya. Oleh karena itu dalam mengatasi kemiskinan, perlu dilakukan secara terpadu dengan menekankan aspek pemberdayaan dalam rangka menumbuhkembangkan etos kerja kemandirian. Adam (2007) mengemukakan bahwa upaya pengentasan kemiskinan harus dilakukan oleh komunitasnya sendiri terutama pada tingkat kelurahan (www.Kimpraswil.go.id/publik/P2KP).

Dalam penelitian ini yang menjadi permasalahan adalah: Permasalahan apa yang dihadapi warga miskin di Provinsi DIY dalam mengembangkan usahanya?; (2) Dapatkah model pemberdayaan lokal dimanfaatkan sebagai wahana pendidikan dalam mengembangkan usaha warga miskin?

Ancok (1999:164) berpendapat bahwa kemiskinan merupakan suatu budaya yang terjadi karena penderitaan ekonomi ('economic deprivation') yang berlangsung lama. Oleh sebab itu, dalam mengatasi kemiskinan dilakukan melalui pendekatan kultural, situasional dan interaksional. Kemiskinan pada 
dasarnya merupakan suatu keadaan ketidakberdayaan seseorang yang berkaitan dengan aspek politik, sosial, lingkungan, ekonomi dan aset produktif. Ketidakberdayaan ekonomi dan asset produktif ditandai oleh kegiatan usahanya kecil, modal usaha sedikit, pangsa pasar terbatas, lahan pertanian sempit, teknologi yang digunakan tradisional, keterbatasan akses ke lembaga keuangan serta terbatasnya informasi pasar.

Dari aspek ekonomi, kemiskinan ditandai oleh rendahnya pendapatan, terbatasnya pemilikan alat produksi, tabungan rendah, serta lemahnya mengantisipasi peluang. Dilihat dari aspek sosial, ditandai oleh keterbatasan interaksi sosial dan penguasaan informasi. Dilihat dari aspek psikologi, ditandai adanya rasa rendah diri, fatalisme, malas, rasa terisolir. Dari aspek politik, terbatasnya fasilitas dan kesempatan, posisi lemah dalam proses pengambilan keputusan, adanya perlakuan yang diskriminatif (Rujito, 2003:75-81).

Banyak pakar yang berpendapat bahwa inti dari masalah kemiskinan adalah masalah budaya, tidak memiliki etos kerja tinggi, tidak memiliki jiwa wiraswasta, dan pendidikan rendah (Tjokrowinoto, 1993:25). Kemiskinan merupakan kondisi serba kekurangan, ketidakberdayaan dan keterbatasan, sehingga untuk mengatasi diperlukan upaya pemberdayaan untuk mengubah nilai-nilai sosial budaya misalnya dengan mensosialisasikan need for achievement, menghilangkan ketergantungan, meningkatkan produktivitas serta mengembangkan kebiasaan hidup yang positif. 
Kemiskinan bukan hanya merupakan masalah ekonomi, melainkan bersifat multidimensional, sehingga kemiskinan harus dilihat dari berbagai aspek. Hal ni sesuai dengan Bank Dunia memberikan pengertian kemiskinan, sebagai berikut:

"Poverty is hunger. Poverty is lack of shelter. Poverty is being, sick and not being able to see a doctor. Poverty is not being go to school and not knowing how to read. Poverty is not having to job, is fear for the future, living one day at a time. Poverty is losing a child to illness brought about by unclean water. Poverty is powerless lack of representation and freedom ( Muchtar : 2003; http: geogle.co.id/muchtar.htm, diakses tgl 29-12-2010).

Hutomo (2000:2) mengemukakan bahwa dalam memahami pemberdayaan terdapat tiga paradigma yakni magical paradigm, native paradigm and critical paradigm. Berdasarkan magical paradigm, bentuk aksi pemberdayaan adalah mengubah sikap mental masyarakat dan memberikan santunan, bantuan modal, maupun pembangunan prasarana pendidikan. Menurut native paradigm, aksi pemberdayaan dilakukan dengan mengubah kebijakan top down menjadi bottom up, mengembangkan sumber daya manusia, dan menguatkan kelembagaannya. Sementara itu, critical paradigm berpandangan bahwa ketidakberdayaan masyarakat disebabkan oleh struktur politik, ekonomi, sosial dan budaya, yang tidak memberi kesempatan bagi masyarakat miskin untuk berpartisipasi dalam bidang ekonomi, politik, sosial budaya.

Tujuan pemberdayaan masyarakat bukan semata-mata untuk menetapkan solusi, melainkan bekerja bersama masyarakat sehingga masyarakat memiliki kemampuan untuk mengatasi masalah yang dihadapi. Pengertian tersebut sejalan dengan pendapat Deepa Narayan yang mengatakan bahwa :"Empowerment is the expansion of assets and capabilities of poor people to participate in, negotiate 
with, influence, control, and hold accountable institutions that affect their lives" (Deepa, 2002:14). Hal ini sejalan dengan Tim Pengendali PNPM Mandiri Perkotaaan bahwa pemberdayaan masyarakat merupakan upaya untuk meningkatkan kapasitas masyarakat, baik secara individu maupun kelompok dalam memecahkan berbagai persoalan terkait upaya peningkatan kualitas hidup, kemandirian, dan kesejahteraanya. (Tim Pengendali PNPM Mandiri Perkotaan, 2007:11)

Dengan demikian, hakekat pemberdayaan merupakan upaya meningkatkan harkat dan martabat lapisan masyarakat dari kondisi tidak mampu untuk melepaskan diri dari perangkap kemiskinan dan keterbelakangan. Pemberdayaan dapat dilakukan melalui tiga jalur, yaitu (1). menciptakan iklim yang memungkinkan potensi masyarakat berkembang (enabling). (2), penguatan potensi dan daya yang dimiliki oleh masyarakat (empowering).dan (3) memberikan perlindungan (protecting) (Somadiningrat, 1999:133-144)

Dalam melaksanakan kegiatan pemberdayaan hendaknya mencakup seluruh anggota masyarakat, baik individu, kelompok maupun lembaga lokal. Lembaga lokal misalnya Rukun Tangga, Rukun Warga, Karang Taruna, kelompok PKK, dan Lembaga Pemberdayaan Masyarakat Desa, Organisasi Koperasi, kelompok Arisan, Kelompok Yandu dan sebagainya dilibatkan secara aktif dalam kegiatan pengentasan kemiskinan dan pengembangan usaha. Dengan dilibatkannya lembaga lokal, maka dalam lembaga lokal akan tumbuh "sense of belonging" merasa ikut memiliki dan bertangungjawab untuk mensuksekan program pengembangan usaha dalam rangka pengentasan kemiskinan. Oleh sebab 
itu, lembaga lokal dapat difungsikan sebagai pendamping dan pelaksana operasional pengembangan usaha di wilayahnya masing-masing, di lain pihak, pemerintah berfungsi melakukan evaluasi dan monitoring berdasarkan pedoman, dan tata kerja yang telah ditetapkan.

Kegiatan usaha yang dilakukan warga miskin pada umumnya termasuk usaha mikro dan usaha kecil bahkan banyak yang berupa usaha informal. Kegiatan usaha warga miskin perlu dikembangkan secara sungguh-sungguh, diberikan perlindungan dan peluang sehingga mampu berkembang, memberikan keuntungan dan pendapatan sehingga mampu mengentaskan dirinya dari kemiskinan. Pengembangan usaha bagi usaha mikro dan kecil (UMK) kiranya sangat penting karena mampu menciptakan kesempatan kerja, meningkatkan pendapatan, mengurangi kemiskinan, mempercepat pemerataan pendapatan dan pembangunan pedesaan (Anoraga, 2002:249).

Berdasarkan hal tersebut dapatlah disusun Kerangka Pikir dan Pengembangan Model Pemberdayaan sebagai berikut.

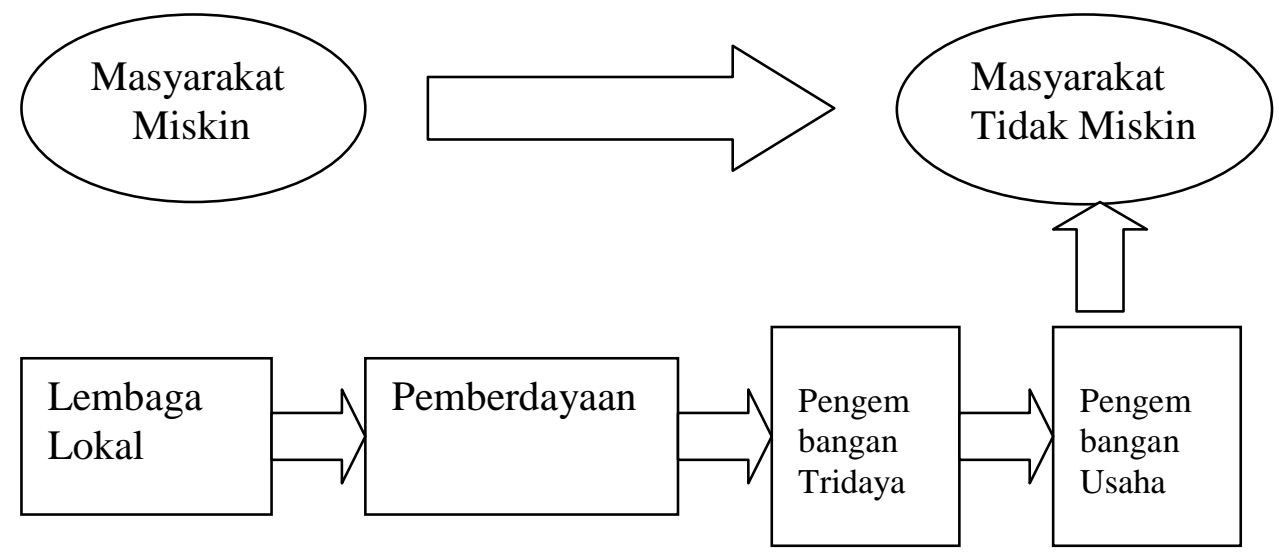

Gambar 1

Kerangka Pikir Model Pemberdayaan Kelembagaan Lokal sebagai Wahana Pendidikan Pengembangan Usaha pada Program Pengentasan Kemiskinan 
Lembaga lokal bertugas membantu penanggulangan kemiskinan dengan cara melakukan pemberdayaan melalui pengembangan program tridaya, yakni pembangunan ekonomi, social dan lingkungan. Pengembangan ekonomi dilakukan dengan memberikan pinjaman modal usaha dengan model tanggung renteng, pembangunan social berupa kegiatan pelatihan untuk meningkatkan keterampilan SDM dan membuka peluang usaha, sedangkan pembangunan lingkungan berupa pembangunan kebersihan dan kesehatan untuk permukiman dan lingkungan, pembangunan sarana perhubungan serta sarana pemasaran.

\section{METODE}

Penelitian ini dilakukan di tiga kabupaten, yaitu Sleman, Bantul, Gunungkidul, dan Kota Yogyakarta. Tiap kabupaten/kota dipilih dua kecamatan sebagai sampel dan tiap kecamatan dipilih satu desa dengan menggunakan sistem acak. Responden dalam penelitian ini berjumlah 204 orang terdiri atas para warga miskin yang memiliki usaha dan tergabung dalam Kelompok Swadaya Masyarakat. Teknik pengumpulan data yang digunakan adalah kuesioner, wawancara, dan dokumentasi. Untuk menganalisis data digunakan teknik analisis kuantitatif dan kualitatif Penelitian ini menggunakan desain R\&D yang dikembangkan oleh Borg \& Gall, dilakukan melalui 10 tahap, yakni: research and information collecting, planning, develop preliminary form of product, preliminary field testing, 
main product revision, main field testing, operational product revision, operational field testing, final product revision, and dissemination and implementation“ (Borg \& Gall, 1983 :275-276).

\section{HASIL DAN PEMBAHASAN}

Berdasarkan kegiatan usahanya, responden umumnya bekerja sebagai usaha mikro dan kecil, misalnya petani, peternak, dagang, penjual makanan dan minuman, pengrajin, buruh serabutan.

\section{Permasalahan Pokok dalam Mengembangkan Usaha}

Permasalahan pokok warga miskin dalam mengembangkan usahanya berupa kekurangan modal (58\%), kekurangan bahan baku (15\%), kesulitan dalam pemasaran (13\%), cuaca kurang baik $(10 \%)$, dan persaingan usaha $(5 \%)$, hama tanaman (4\%), harga pakan mahal (2\%)dan kurangnya keterampilan. Adapun cara mengatasi yang telah dilakukan selama ini adalah mencari pinjaman di kelompok arisan (56\%); ke rentener (20\%), membeli bahan melalui kelompok (9\%), melakukan promosi $(8 \%)$, menyesuaikan dengan cuaca $(9 \%)$, meningkaatkan mutu (8\%), melakukan penyemprotan $(5 \%)$ dan meningkatkan kerjasama dengan $\operatorname{dinas}(2 \%)$.

\section{Pemberdayaan Terhadap Kelembagaan Lokal}

Kelembagaan lokal dalam Program PNPM Mandiri Perkotaan dibentuk atas prakarsa masyarakat, atas dasar kerelawanan, tanggungjawab dan kepedulian 
sosial. Mereka yang duduk sebagai anggota BKM adalah orang-orang yang dipercaya, memiliki kepedulian sosial yang tinggi, memiliki kerelawanan yang tinggi dalam rangka mengentaskan kemiskinan di wilayahnya masing-masing. Oleh karena itu, lembaga lokal BKM merupakan lembaga yang dipercaya oleh masyarakat untuk memperjuangkan nasib warga miskin melepaskan diri dari jeratan kemiskinan melalui program pembangunan tridaya, yang berupa pembangunan bidang ekonomi, sosial dan lingkungan. Untuk memperkuat keberadaan lembaga lokal BKM, Komite Manajemen Wilayah (KMW) melakukan kegiatan pemberdayaan untuk mengembangkan potensi dan kemampuan BKM, sehingga BKM mampu melaksakan fungsi dan perannya dalam pengentasan kemiskinan di wilayahnya.

Adapun kegiatan pemberdayaan yang dilakukan oleh KMW terhadap lembaga lokal BKM adalah sebagai berikut.

a. Memberikan pelatihan kepada koordinator dan anggota BKM tentang tugas dan fungsinya dalam program pengentasan kemiskinan, dilakukan selama tiga hari bertempat di Kantor Pemerintah Daerah Kabupaten.

b. Memberikan pelatihan seluruh anggota BKM dan tokoh masyarakat tentang nilai-nilai luhur dan prinsip-prinsip BKM.

c. Memberikan pelatihan cara penyusunan Peta Swadaya Masyarakat, dilaksanakan selama tiga hari bertempat di Kantor Desa setempat

d. Memberikan pelatihan pengelolaan keuangan dan program kerja, dilaksanakan oleh Fasilitator Kelurahan. 
e. Memberikan pendampingan BKM dalam penyusunan program pembangunan tridaya (pembangunan ekonomi, sosial dan lingkungan), kerja, penyusunan anggaran belanja, penyusunan laporan.

f. Memberikan pendampingan BKM dalam melaksanakan dan monitoring pelaksanaan pembangunan tridaya.

g. Melibatkan BKM dalam Musyawarah Rencana Pembangunan (Musrenbang) baik pada tingkat kelurahan maupun kecamatan.

\section{Pemberdayaan sebagai Wahana Pendidikan Pengembangan Usaha}

Kegiatan pemberdayaan lembaga lokal dilakukan terhadap kelompo usaha warga miskin dengan cara (a) memberikan pelatihan kepada pengurus lembaga lokal; (b) memberikan pendampingan lembaga lokal oleh fasilitator kelurahan; (c) secara rutin melibatkan lembaga lokal dalam penyusunan program dan (d) memberikan kepercayaan kepada lembaga lokal untuk melaksanakan dan memonitor program.

Kelompok Swadaya Masyarakat (KSM) merupakan kumpulan para warga miskin yang memiliki usaha. KSM merupakan sasaran program PNPM Mandiri Perkotaan. Kegiatan usaha KSM pada umumnya tergolong sebagai usaha mikro, merupakan sektor informal, dengan modal kecil, tidak memiliki ijin usaha, belum melakukan pembukuan, anggota keluarga sebagai tenaga kerja, produknya terbatas serta pengelolaannya masih tradisional. Dalam rangka meningkatkan pengembangan usaha KSM, BKM melakukan serangkaian pendidikan dan pelatihan dalam rangka mengembangkan usaha anggota KSM. Adapun tanggapan 
anggota KSM terhadap kegiatan pendidkan dan pelatihan disajikan dalam tabel 1 berikut.

Tabel 1. Pendapat Responden atas Tingkat Kemanfaatan Pemberdayaan sebagai Sarana Pendidikan Pengembangan Usaha KSM

\begin{tabular}{|c|c|c|c|c|c|c|c|}
\hline \multirow{3}{*}{ No. } & \multirow{3}{*}{ Kegiatan } & \multicolumn{6}{|c|}{ Kemanfaatan } \\
\hline & & \multicolumn{2}{|c|}{ Tinggi } & \multicolumn{2}{|c|}{ Sedang } & \multicolumn{2}{|c|}{ Kurang } \\
\hline & & Jml & $\%$ & Jml & $\%$ & Jml & $\%$ \\
\hline 1. & $\begin{array}{l}\text { Pelatihan Pembuatan makanan } \\
\text { dari bahan lokal }\end{array}$ & 174 & 85 & 18 & 9 & 12 & 6 \\
\hline 2. & $\begin{array}{l}\text { Pelatihan Ketrampilan Salon } \\
\text { potong rambut }\end{array}$ & 146 & 71 & 50 & 25 & 8 & 4 \\
\hline 3. & Pelatihan menjahit & 190 & 93 & 14 & 7 & 0 & 0 \\
\hline 4. & $\begin{array}{l}\text { Pelatihan Ketrampilan Bengkel } \\
\text { motor }\end{array}$ & 136 & 67 & 48 & 23 & 20 & 10 \\
\hline 5. & $\begin{array}{l}\text { Program Bea Siswa Anak } \\
\text { Berprestasi Tingkat SD dan SMP }\end{array}$ & 198 & 97 & 6 & 3 & 0 & $\mathbf{0}$ \\
\hline 6. & Bantuan Pendaftaran Masuk SMP & 68 & 33 & 122 & 60 & 14 & 7 \\
\hline 7. & $\begin{array}{l}\text { Bantuan Peralatan Sekolah Anak } \\
\text { Berprestasi Tingkat SD dan SMP }\end{array}$ & 120 & 59 & 74 & 36 & 10 & 5 \\
\hline 8. & $\begin{array}{l}\text { Pendampingan Pemeliharaan } \\
\text { Itik (Bantuan Bergulir) }\end{array}$ & 160 & 78 & 38 & 19 & 6 & 3 \\
\hline 9. & $\begin{array}{l}\text { Pendampingan Pemeliharaan } \\
\text { Kambing (Bantuan Bergilir) }\end{array}$ & 190 & 93 & 10 & 5 & 4 & 2 \\
\hline 10. & $\begin{array}{l}\text { Pendampingan Pemanfaatan } \\
\text { Pinjaman Bergulir }\end{array}$ & 198 & 97 & 4 & 2 & 2 & 1 \\
\hline 11. & $\begin{array}{l}\text { Pendampingan Pembangunan } \\
\text { Kesehatan Permukiman }\end{array}$ & 168 & 82 & 24 & 12 & 12 & 6 \\
\hline 12. & $\begin{array}{l}\text { Pendampingan Pembangunan } \\
\text { Sarana Perhubungan }\end{array}$ & 86 & 42 & 78 & 38 & 40 & 20 \\
\hline 13. & $\begin{array}{l}\text { Pendampingan Pemanfaatan } \\
\text { Sentra Produksi Tahu }\end{array}$ & 128 & 63 & 54 & 26 & 22 & 11 \\
\hline 14. & $\begin{array}{l}\text { Pendampingan Difersifikasi } \\
\text { PemanfaatanAmpas Tahu }\end{array}$ & 116 & 57 & 68 & 33 & 20 & 10 \\
\hline & Rata-rata & & 81 & & 15 & & 4 \\
\hline
\end{tabular}

Kegiatan pendidikan yang dilakukan oleh BKM, yang berupa kegiatan pelatihan, pembimbingan, pendampingan dirasakan bermanfaat terbukti sebanyak $81 \%$ responden menyatakan manfaatnya tinggi dan hanya $4 \%$ yang menyatakan kurang bermanfaat. Program BKM secara langsung dirasakan bermanfaat bagi 
pengembangan usaha warga miskin adalah program pinjaman bergulir. Sasaran pinjaman bergulir bukan perorangan melainkan kelompok usaha. Pinjaman bergulir diperuntukkan bagi Kelompok Swadaya Masyarakat (KSM), yaitu kelompok yang beranggotakan 5-15 orang warga miskin yang memiliki usaha. Adanya kelompok usaha diharapkan jiwa kebersamaanya makin meningkat, sehingga berbagai permasalahan yang dihadapi dapat diselesaikan secara bersama. Dengan adanya pinjaman bergulir diharapkan dapat mengatasi kekurangan modal usaha, disamping sebagai upaya untuk melepaskan diri mereka dari pinjaman rentener yang dirasakan sangat berat.

Meskipun telah diberikan bimbingan dan pengarahan dalam penggunaan pinjaman bergulir, dari $59 \mathrm{KSM}$ yang diteliti, terdapat $30 \mathrm{KSM}$ usahanya berhasil dan sebanyak 29 KSM mengalami kegagalan. Keberhasilan usaha tidak terlepas dari bagaimana pemanfaatan pinjaman bergulir dan jenis penggunaan dipengaruhi oleh tingkat pendidikan mereka. Selain itu, dapat disimpulkan bahwa terdapat hubungan tingkat pendidikan warga miskin terhadap penggunaan pinjaman bergulir maupun keberhasilan usaha.

Tabel 2. Hubungan Tingkat Pendidikan dan Penggunaan Pinjaman Bergulir pada KSM Yang Gagal

\begin{tabular}{lccccccc}
\hline \multirow{2}{*}{$\begin{array}{c}\text { Tingkat } \\
\text { pendidikan }\end{array}$} & \multicolumn{9}{c}{ Penggunaan Pinjaman Bergulir } & Kembeli & Modal & Jumlah & \% \\
& Kebutuhan & Biaya & $\begin{array}{c}\text { Mehari-hari } \\
\text { sekolah }\end{array}$ & kendaraan & usaha & & \\
\hline SD atau sederajat & 2 & 0 & 0 & 0 & 2 & 7 \\
SMP / sederajat & 6 & 4 & 0 & 5 & 15 & 52 \\
SMA / sederajat & 4 & 3 & 2 & 3 & 12 & 41 \\
Perguruan Tinggi & 0 & 0 & 0 & 0 & 0 & 0 \\
\hline Jumlah & 12 & 7 & 2 & 8 & 29 & 100 \\
Persentase & 41 & 24 & 7 & 28 & 100 & \\
\hline
\end{tabular}


Tabel 3. Hubungan Tingkat Pendidikan dan Penggunaan Pinjaman Bergulir pada KSM Yang Berhasil

\begin{tabular}{lcccccc}
\hline \multirow{2}{*}{$\begin{array}{l}\text { Tingkat } \\
\text { Pendidikan }\end{array}$} & \multicolumn{9}{l}{ Penggunaan Pinjaman Bergulir } & & & \\
\cline { 2 - 5 } & $\begin{array}{l}\text { Kebutuhan } \\
\text { sehari-hari }\end{array}$ & $\begin{array}{l}\text { Biaya } \\
\text { sekolah }\end{array}$ & $\begin{array}{l}\text { Membeli } \\
\text { kendaraan }\end{array}$ & $\begin{array}{l}\text { Modal } \\
\text { usaha }\end{array}$ & Jumlah & $\%$ \\
\hline SD atau sederajat & 0 & 0 & 0 & 2 & 2 & 7 \\
SMP/sederajat & 2 & 0 & 0 & 3 & 5 & 16 \\
SMA/sederajat & 6 & 3 & 1 & 10 & 20 & 67 \\
Perguruan Tinggi & 0 & 1 & 0 & 2 & 3 & 10 \\
\hline Jumlah & 8 & 4 & 1 & 17 & 30 & 100 \\
Persentase & 27 & 13 & 3 & 57 & 100 & \\
\hline
\end{tabular}

Tingkat pendidikan para anggota KSM Gagal lebih rendah dibanding dengan KSM Berhasil. Pada KSM Gagal, 59\% berpendidikan dasar, dan 41\% berpendidikan SLTA dan tidak ada yang berpendidikan tinggi. Sedangkan pada KSM Berhasil, 23\% berpendidikan dasar, $67 \%$ berpendidikan SLTA dan 10\% berpendidikan perguruan tinggi. Dilihat dari penggunaan pinjaman bergulir, para responden yang tingkat pendidikannya tinggi cenderung menggunakan pinjaman bergulir untuk menambah modal usaha, sedangkan KSM yang berpendidikan rendah, penggunaan pinjaman bergulir cenderung untuk memenuhi kebutuhan sehari-hari. Adapun gambaran riilnya sebagai berikut : Pada KSM Gagal hanya $28 \%$ dari mereka yang menggunakan pinjaman bergulir untuk modal usaha, $41 \%$ untuk memenuhi kebutuhan seharai-hari dan $24 \%$ untuk biaya sekolah. Sedangkan pada KSM Berhasil, sebanyak 57\% mengunakan pinjaman bergulir untuk modal usaha, $27 \%$ untuk memenuhi kebutuhan sehari-hari dan $13 \%$ untuk biaya sekolah.

Dari data ini diketahui bahwa program pinjaman bergulir belum sepenuhnya mencapai tujuan, mengingat baru sebesar $28 \%$ hingga $57 \%$, responden yang menggunakan pinjaman bergulir untuk modal usaha, dan 
selebihnya untuk memenuhi kebutuhan sehari-hari. Hal ini tidak sesuai dengan maksud diselenggarakannya pinjaman bergulir adalah untuk mencukupi kekurangam modal usaha dalam rangka mengembangkan usaha ekonomi mereka. Sehubungan dengan itu kiranya perlu dilakukan penyuluhan guna meningkatkan kesadaran akan perlunya memanfaatkan pinjaman untuk kegiatan yang produktif dan menghindarkan diri penggunaan pinjaman hanya untuk konsumsi.

Tabel 4. Dampak Tidak Langsung Pelaksanaan Program Tridaya (Pinjaman Bergulir, Pelatihan, dan Pembangunan Lingkngan) di Desa Margoagung Kabupaten Sleman

\begin{tabular}{|c|c|c|}
\hline No. & Kegiatan & Dampak Tidak Langsung \\
\hline 1. & Pinjaman Bergulir & $\begin{array}{l}\text { Tidak lagi ,meminjam ke rentener } \\
\text { Sadar untuk hidup hemat } \\
\text { Menguatnya kerukunan anggota KSM } \\
\text { Semangat usaha makin kuat }\end{array}$ \\
\hline 2. & Pelatihan Keterampilan & $\begin{array}{l}\text { Wawasan usaha makin luas } \\
\text { Timbul semangat untuk usaha } \\
\text { Terbentuknya kelompok usaha }\end{array}$ \\
\hline 3. & Pembangunan Lingkungan & $\begin{array}{l}\text { Meningkatnya kegiatan gotongroyong } \\
\text { Meningkatnya kesadaran kebersihan } \\
\text { lingkungan } \\
\text { Pembangunan MCK meningkat } \\
\text { Perbaikan rumah sehat }\end{array}$ \\
\hline
\end{tabular}

\section{SIMPULAN DAN SARAN}

\section{Simpulan}

Berdasarkan pembahasan hasil penelitian tersebut, dapatlah disimpulkan sebagai berikut. 
a. Model pemberdayaan kelembagaan lokal dapat digunakan sebagai sarana untuk meningkatkan partisipasi warga dalam pengentasan kemiskinan.

b. Kegiatan pemberdayaan dapat digunakan sebagai wahana pendidikan bagi pengenbangan usaha warga miskin.

c. Kegiatan pemberdayaan digunakan sebagai wahana pendidikan dilakukan melalui kegiatan pendidikaan, pelatihan dan pendampingan baik kepada lembaga lokal maupun kelompok usaha.

d. Para anggota KSM yang tingkat pendidikannya tinggi cenderung menggunakan pinjaman bergulir untuk modal usaha, dan para anggota KSM yang tingkat pendidikannya rendah cenderung menggunakan untuk memenuhi kebutuhan sehari-hari.

e. Tujuan program pinjaman bergulir belum sepenuhnya berhasil, mengingat aanggota KSM yang menggunakannya untuk modal usaha antara 28 sampai dengan $57 \%$ dan sebanyak $27 \%$ sampai dengn $41 \%$ menggunakan untuk memenuhi kebutuhan konsumsi.

\section{Saran}

a. Perlunya meningkatkan kesadaran para anggota KSM agar pinjaman bergulir digunakan untuk kegiatan yang produktif misalnya untuk menambah modal usaha, membeli peralatan, maupun membeli bahan mentah. 
b. BKM sebagai lokal perlu memberikan pendampingan yang intensif kepada KSM dalam pemanfaatan pinjaman bergulir benar-benar digunakan untuk kegiatan yang produktif.

c. Program pinjaman bergulir perlu dilanjutkan dan dipertahankan keberadaannya karena memberikan dampak berkurangnya anggota KSM yang mencari pinjaman modal dari rentener.

\section{UCAPAN TERIMA KASIH}

Terima kasih kami sampaikan kepada Dewan Redaksi dan staf Jurnal Cakrawala Pendidikan Universitas Negeri Yogyakarta yang telah memberikan saran dan perbaikan naskah ini. Terima kasih juga kami sampaikan kepada Ditjen Dikti khsusunya Tim Hibah Bersaing yang telah memberikan kesempatan dan mendanai penelitian ini. Tidak lupa kami sampaikan terimakasih kepada Prof Dr.Aliyah Rasyid dan Fx Sudarsana, Ph.D. selaku promotor yang dengan sabar dan penuh ketekunan memberikan bimbingan dan pengarahan penulisan artikel ini. Semoga ALLAH Yang Maha Kuasa memberikan pahala kepada semua pihak yang telah memberikan bantuannya.

\section{DAFTAR PUSTAKA}

Ancok, Djamaludin. 1999. Kemiskinan dan Kesenjangan di Indonesia : Pemanfaatan Organisasi Lokal untuk Mengentaskan Kemiskinan. Yogyakarta : Aditya Media bekerjasama dengan ICMI Pusat, ICMI Orwil DIY PPSK Yogyakarta.

Anoraga, Panji dan Djoko Sudantoko. 2002. Koperasi, Kewirausahaan, dan Usaha Kecil. Jakarta: Rineka Cipta 
Borg R Walter \& Gall, Meredith D. 1983. Educational Research : An Introduction, New York : Routlegde.

Deepa Narayan 2002. Empowerment And Poverty Reduction : A Sourcbook. Washington, The World Bank

Hutomo, Mardi Yatmo. 2000. Pemberdayaan Masyarakat dalam Bidang Ekonomi: Tinjauan Teoretik dan Implementasi. Makalah disampaikan pada Seminar Sehari Pemberdayaan Masyarakat yang diselenggarakan oleh Bappenas tanggal 6 Maret 2000 di Jakarta.

Muchtar. 2003. Strategi Pemberdayaan Berbasis Kelembagaan Lokal dalam Penangangan Kemiskinan Perkotaan : Kasus Implementasi P2KP di Desa Sukadanau". Jakarta : BPS bekerjasama dengan Depsos RI :Laporan Penelitian dan (http:geogle.co.id Nmuchtar.htm, download tanggal 29 Desember 2007\}.

Nugroho, Heru. 1999. Kemiskinan, Ketimpangan dan Pemberdayaan : Kemiskinan dan Kesenjangan di Indonesia. Yogyakarta : Aditya Media bekerjasama dengan ICMI Pusat, ICMI Orwil DIY PPSK Yogyakarta.

Rujito. 2003. Pengenasan Kemiskinan. Jurnal Ekonomi Rakyat No.1 Maret 2003. Yogyakarta : Bank Rakyat Indonesia.

Somadiningrat, Gunawan. 1999. Pemberdayaan Masyarakat dan JPS. Jakarta: Gramedia.

Tim Pengendali PNPM Mandiri. 2007. Pedoman Umum Program Nasional Pemberdayaan Masyarakat (PNPM) Mandiri. Jakarta : Ditjen Cipta Karya

Tjokrowinoto. Moeljarto. 1993. Strategi Alternatif Pengentasan Kemiskinan. Makalah untuk Seminar Bulanan P3PK,UGM.

www.Kimpraswil.go.id/publik/P2KP. Program Pengentasan Kemmiskinan. 2003. 
